\title{
KOBIETY NA BIEŻNI \\ DO SATYSFAKCJONUJĄCYCH RELACJI PARTNERSKICH I RODZINNYCH W KULTURZE CELEBRUJĄCEJ "JA"
}

\begin{abstract}
Młodkowska Mirosława, Kobiety na bieżni do satysfakcjonujacych relacji partnerskich i rodzinnych w kulturze celebrujacej "Ja" [Women in their Race to Satisfying Partner and Family Relationship in the Culture Focused on the "I" Rather Than "We"]. Studia Edukacyjne nr 50, 2018, Poznań 2018, pp. 307-320. Adam Mickiewicz University Press. ISSN 1233-6688. DOI: 10.14746/se.2018.50.20

The article aims at approximating the socio-cultural dimension of contemporary requirements of women, especially women who are socially imposed by the codes of self-improvement and satisfaction in almost every sphere of life: partnership, intellectual, family, sexual, aesthetic, professional. The article is divided into three parts. The first part, entitled "The run for liberation or alienation, narcissism and frustration", discusses the evolution of the "Polish Mother" stereotype into that of the "superhero" type. The following part describes the conflict between women's need for recognition and self-exclusion on their way to happiness. The last part designates the quest for recognition among items that satisfy the consumption hunger and escalate the hunger for recognition, simultaneously causing a natural disintegration of women's inner power.
\end{abstract}

Key words: relationship, women in the culture of narcissism, value of recognition, superhero type

Kobieta wspótczesna to wir aktywności. Świat zmusza ja, by była wszystkim dla wszystkich (...) Uderzające sa podobieństwa w bezlitosnym tępieniu wilków i kobiet przez tych, którzy ich nie rozumieja

Clarissa Pinkola Estes ${ }^{1}$

\section{Wstęp}

Kobiety i kobiecość od lat stanowią ważny punkt odniesienia dla myśli, czy sporów feministycznych. Na temat kobiecości jako wciąż „niedomkniętej

${ }^{1}$ C.P. Estes, Biegnaca z wilkami. Archetyp dzikiej kobiety w mitach i legendach, Poznań 2001, s. 11-12. 
i transformującej się kategorii" (wg Rosi Braidotti) ${ }^{2}$ wypowiadają się same kobiety, a debatę rozpoczął ruch feminizmu, świadomie odzyskujący prawa do przedstawiania kobiecości przez same kobiety, ale nie mający większego sensu bez praktyki politycznej, zbiorowego działania i szeroko pojętych działań w kierunku uświadamiania społecznego.

Projekt zwany feminizmem, między innymi w Polsce jest wciąż niedomknięty, a wyzwolenie kobiet często przyjmuje wyłącznie prowizoryczny wymiar samodoskonalenia, czy też zachowań prowokowanych przez kulturę celebrująca jednostkowe dobro. $Z$ kolei, w temacie rodzinności i partnerstwa istotny jest mit Matki Polki, od którego współczesne młode kobiety z jednej strony uciekają, ale który przeistoczył się w superbohaterki - matki, żony, córki - stuprocentowo aktywne i biegnące na bieżni do tak zwanego szczęśliwego i satysfakcjonującego życia.

Artykuł ma na celu przybliżyć społeczno-kulturowy wymiar współczesnych wymagań stawianych kobietom, a dokładnie kobiet obciążonych narzuconymi społecznie kodami samodoskonalenia i satysfakcji w niemal każdej sferze życia: partnerskiego, intelektualnego, rodzinnego, seksualnego, estetycznego, zawodowego. Z drugiej strony kobiet, które określa się pejoratywnym typem tak zwanej "karierowiczki”, odrzuconym przez kobiety będące $w$ domu i wychowujące dzieci oraz przez mężczyzn, którzy akceptują i niezwykle cenią taką matkę i żonę. Osiągnięcie „pełni szczęścia” na każdym $\mathrm{z}$ wymienionych poletek przypomina bieg na bieżni. Symboliczna bieżnia metafora zapożyczona od Zygmunta Baumana ${ }^{3}$ - to nie tylko tor wyścigowy, na którym ciało poddawane jest nieustannej dyscyplinie, ale także miejsce, gdzie nie można choć na ułamek chwili zwolnić, a tym bardziej się zatrzymać. Bieżnia, na której ćwiczą biegacze $\mathrm{w}$ klubach fitness jest $\mathrm{w}$ kształcie elipsy lub okręgu, symbolizuje nudny, niekończący się ruch w zamkniętym pomieszczeniu, bez kontaktu z przyrodą, ale też bez większego celu, refleksji, czy sensu. Artykuł nie będzie dotyczył wielości odmian i definicji kobiecości, ani też upodobań, usposobień, poglądów społeczno-kulturowych oraz wielości kodów i aspektów obejmujących wszystkie kobiece role. Rozważania o kobietach będących na bieżni zarysowują raczej problem społeczny, który z pewnością nie dotyczy każdej szeroko zróżnicowanej grupy kobiet, o którym nie można i nie sposób wypowiadać się jako o ujednoliconym w barwnej przestrzeni relacji i ról kobiecych. Inspiracją do napisania tekstu o kobietach będących w ciągłym ruchu było uczestnictwo $\mathrm{w}$ wymianie myśli na temat "Stulecia praw kobiet”, w podstoliku zorganizowanym przy okazji Zjazdu

${ }^{2}$ J. Wodzik, Czy kobieta istnieje? Spór o pojęcie kobiecości pomiędzy esencjalizmem i antyesencjalizmem we wspótczesnej myśli feministycznej, Warszawa 2016, s. 230.

${ }^{3}$ Z. Bauman, Sztuka życia, Kraków 2009, s. 68-69. 
Pedagogów Społecznych w Poznaniu 4 . Pytanie, które się wówczas nasunęło, a zarazem zainspirowało: Minęło sto lat od nadania kobietom praw wyborczych, czy od tego czasu wiele uległo zmianie, a skoro tak, to dlaczego kobiety wciąż muszą się starać o uświadamianie społeczne swoich praw?

\section{Bieg wyzwolenia czy alienacji, narcyzmu i frustracji?}

Czy współczesne kobiety biegną, czy raczej uciekają (od: miłości „do grobowej deski", jednego miejsca zamieszkania, stałego zatrudnienia, macierzyństwa)? Czy współczesne kobiety oddalają wszelkie zobowiązujące i wymagające czasu oraz poświęcenia działania na odpowiedni moment, który może nigdy nie nastąpić? Jeśli współczesne kobiety uciekają, jednocześnie biegnąc do samospełnienia, do samorealizacji w edukacji, w sferze zawodowej, to kto lub co narzuca im tempo owego joggingu, kto lub co każe im nieustannie być w ruchu i tracić oddech? Przez co lub przez kogo są poganiane, czy w owych wyścigach rywalizują z mężczyznami, czy dzięki wysiłkowi wytwarzają się w nich endorfiny - hormony szczęścia, czy wręcz przeciwnie - pogłębione we frustracji, coraz mniej empatyczne i troskliwe o innych, wciąż pragną zadowolenia? Wszystkie pytania osadzam $\mathrm{w}$ zauważalnym społecznym wyścigu, za który nie winię ambitnych i pracowitych kobiet, tak zasłużonych dla rozwoju kultury, sztuki, historii, ani dominujących, czy będących w kryzysie mężczyzn. Aby móc przyjrzeć się uważniej biegowi wyzwolenia czy alienacji, ciekawy jest kontekst społeczno-kulturowy, w którym znalazły się odważne kobiety i ujawniający swoje słabości mężczyźni. Christopher Lasch ${ }^{5}$ dostrzega efekt spsychologizowanych jednostek, czyli analizujących, oceniających, ale tylko przez pryzmat własnych - narcystycznych interesów, u których dominującą emocją jest niepokój, a ewentualne kryterium zbliżenia się do drugiej osoby stanowi indywidualne dobro i własne zdrowie psychiczne.

Wszystkie podziwiane w świecie show-biznesu piękne, wyzwolone i młode kobiety na łamach kolorowych pism podążają za, narzuconym społecznie, tak zwanym szczęściem, czyli tempem wzrostu, rozwoju, samodoskonalenia, uwielbiają być adorowane, choć to nie zapewnia im uznania. Narcyzm kulturowy nigdy nie jest siłą motywującą, bo jedyną domenę jaką promuje można zawrzeć w egocentrycznym stwierdzeniu "tylko ja i moje sprawy". Za Ch. Laschem „pogoń za szczęściem doprowadza do ślepego zaułka narcystycz-

${ }^{4}$ Zjazd Pedagogów Społecznych odbył się 17 września 2018 roku w Poznaniu, zorganizowany przez Wydział Studiów Edukacyjnych Uniwersytetu im. Adama Mickiewicza oraz Akademię Pedagogiki Specjalnej im. Marii Grzegorzewskiej w Warszawie.

${ }^{5}$ Ch. Lasch, Kultura narcyzmu, Warszawa 2015. 
nej troski o »ja «"6. Kultura narcyzmu jako projekt samodoskonalenia uparcie i bezkompromisowo narzuca fałsz oraz manipulację, odbierając wolność w działaniu i odczytywaniu swoich wewnętrznych pragnień. Szczęście, do którego trzeba pokonać długi dystans na nudnej bieżni, zostało wyrugowane przez próżną i krótkotrwałą konsumpcję. $\mathrm{W}$ takich warunkach kobiety poganiane i zwabiane na bieżnię sukcesu, wyzwolenia, uznania i podziwu, w konsekwencji doświadczają samotności i alienacji, bo okazuje się, że to co kiedyś stanowiło o ich oryginalności, niepowtarzalności i kapitale społeczno-ekonomicznym, a więc odpowiednie pochodzenie, zamożność i talenty zostało przekonwertowane jedynie na ich zewnętrzne atrybuty i seksualność. Kobiety wkładają ogromny wysiłek, aby utrzymać tempo biegu na bieżni i sprostać oczekiwaniom społecznym dotyczącym atrakcyjności fizycznej, oryginalności, potrzeby bycia na piedestale uznania i podziwu ze strony otoczenia, są aktywnymi konsumentami coachingu zdrowia, coachingu kulinarnego, coachingu urody. Prześcigają się w pomysłach na udoskonalenie Siebie, na oryginalną autoprezentację, na wyretuszowanie niedoskonałości, z jednej strony chcąc być odpowiednimi partnerkami dla swoich wybranków, z drugiej strony przerysowując swoją atrakcyjność, siłę i zaradność bez udziału mężczyzn w ich życiu. W relacjach oczekują raczej partnerstwa, czyli równego podziału ról, możliwości spełnienia w każdej sferze, rozwoju swoich zainteresowań i pasji. Zdaje się że baumanowskie słowo miłość, rozumiane jako „bastion przeciwko widmu samotności i falochron chroniący (...) przed sztormem na szalejącym otwartym morzu"7, jest współcześnie mocno przesadzone, bowiem ani kobiety, ani mężczyźni nie szukają schronienia w ramionach partnerów, raczej chcą równoprawnego towarzysza, który pozwoli na przestrzeń oddzielnych ról i zadań, który nie boi się samotności, bo nieustannie biegnie, więc jej nie odczuwa. Przesadna koncentracja na aktualnym biegu spraw, wydarzeń, uczestnictwo we wszystkich „wartych uwagi" wydarzeniach i informowanie o nich swojego otoczenia, może sprowokować do oddalenia od fizycznej bliskości i intymności w relacji partnerskiej, może też oddalić od wartości piękna absolutnego, rozumianego jako mądrość obecna w życiu kobiet od wieków czerpiących siłę właśnie w skupieniu i samotności, co najdotkliwiej uobecnia się w krótkotrwałych i zmiennych relacjach rodzinnych oraz partnerskich. Cel, który uobecnił się w kulturze pod wpływem antropologicznego dzieła - światowego bestselleru Biegnaca z wilkami. Archetyp dzikiej kobiety $w$ mitach $i$ legendach, napisanej z początkiem lat dziewięćdziesiątych ubiegłego stulecia, sprowadził autorkę do poszukiwań kobiecych instynktów, które właśnie pod wpływem biegu i bycia „wszystkim dla wszystkich”

\footnotetext{
6 Tamże, s. 23.

7 Z. Bauman, Sztuka życia, Kraków 2009.
} 
straciły sens. Autorka przez wiele lat w mitach i legendach doszukiwała się siły kobiet, którą przyrównywała do siły wilków, w roli dociekliwej i współuczestniczącej badaczki odnalazła konkretne analogie:

Zdrowe wilki i zdrowe kobiety podzielają pewne cechy psychiczne: wyczulone zmysły, duch zabawy, ogromną zdolność do poświęceń. Wilki i kobiety to istoty z natury pokrewne, są dociekliwe, bardzo silne i odporne. Mają głęboką intuicję, z poświęceniem troszczą się o potomstwo, partnerów i stado. Potrafią się doskonale przystosować do wciąż zmieniających się warunków, odznaczają się silnym charakterem i wielką odwagą ${ }^{8}$.

Zdaje się, że współczesne biegnące kobiety zapominają o misji do poświęceń, sprzeciwiając się jej, nie chcąc stawiać siebie w roli uległej, czyli słabszej, tej która się poświęca, bowiem niemal każde wykonywane przez nie zadanie podlega oszacowaniu kosztów i strat. Wyraźny efekt takiej postawy zauważyłam badając współczesne relacje partnerskie wśród studentów polskich i czeskich, gdzie wypowiedź kobiet niejednokrotnie sprowadziła się do skryptu biografii relacji ponowoczesnej - Jesteśmy razem, ale osobno, Jesteśmy razem w epoce Ja9 .

W kwestii kobiet odważnych, walczących o swoje prawa, samowystarczalnych i niezwyciężonych wypowiadali się również mężczyźni, w tym między innymi psychoanalityk Jacques Lacan ${ }^{10}$. Psychoanaliza Lacana przez jednych odbierana jako wspierająca dla ówczesnego francuskiego ruchu feministycznego, przez innych analizowana wyłącznie przez pryzmat psychoanalizy Zygmunta Freuda, zaowocowała wartościową ze społecznego i feministycznego punktu widzenia definicją miłości (uzupełnianą także przez Slavoi Zizka):

„Miłość to dawanie tego, czego nie mamy, komuś, kto tego nie potrzebuje”.

Zatem, do miłości pcha pewien nieświadomy motor, pewien brak, który jest dostrzegalny dopiero dzięki obecności drugiego. W takim układzie kochany uzupełnia kochającego czymś, czego nie widać, czego nawet nie potrafi nazwać słowami, a co sprawia, że spada w dół. Oddaje to trafne określenie na zakochanie w języku angielskim fall in love - spadać w dół, zatracać się. To druga osoba w relacji ma coś, co nas do niej przyciąga, co czaruje, tylko to jest warunkiem zbliżenia się do niej. To właśnie kobiety są przyczyną owego zbliżenia i pragnienia, a nie jego obiektem. Kobieta zatem, według Lacana, jest przyczyną pragnienia, jest najważniejszym elementem aktywnym, a nie pasywnym w relacji. Zapominają o tym kobiety, które walczą o wyzwolenie

${ }^{8}$ C.P. Estes, Biegnaca z wilkami, s. 12.

${ }_{9}$ M. Ściupider-Młodkowska, Miłość w epoce Ja. Studium socjopedagogiczne, Poznań 2018, s. $240-249$.

10 J. Lacan, Pisma techniczne Freuda, Warszawa 2017. 
i podmiotowe, partnerskie traktowanie $\mathrm{w}$ relacji, stawiając siebie $\mathrm{w}$ pozycji pasywnej uległej i niższej, czy niesprawiedliwie traktowanej względem mężczyzn. Być może fakt ten wpływa na współczesne rozumienie miłości, która przestaje mieć sens, czar zakochania i kochania pryska, bo troska i dbałość o drugiego zamiast poświęcenia wpisanego $\mathrm{w}$ kobiecą naturę, przemienia się w oczekiwania względem partnera. Aktywne kobiety zaangażowane we wspólną relację, pełne poświęcenia dla innych zamieniły się w pielęgnujące i troszczące się wyłącznie o siebie, wzmacniające swoje ego. Autoafirmacyjne skłonności dośrodkowe, które według Baumana umożliwiają „praktykowanie wsobnych, autoreferencyjnych pragnień"11, z jednej strony mogą poprawić jakość społecznego funkcjonowania dbających o swoją kobiecość i skoncentrowanych na sobie kobiet, $\mathrm{z}$ drugiej strony istnieje ryzyko uprzedmiotowienia relacji i ogólnego wcielania do nich narcystycznego projektu Ja i moje odbicie.

\section{Bieg uznania czy wykluczania?}

Abjects - skrajni, nędzni, wykluczeni - Inni, to słowo najczęściej pojawia się $w$ feministycznych analizach Judith Butler, dla której działanie $w$ imię uniwersalnego podmiotu, jakim są kobiety, ",tworzy nowe tereny wykluczeń, prowokuje opór i rozdrobnienie"12. Większość współczesnych feministek dostrzega błąd w mówieniu i pisaniu o kobietach jako ujednoliconej grupie, twierdzą, że są to opinie krótkowzroczne, potęgujące władzę jednych kobiet nad innymi oraz przyczyniające się do wykluczenia praw jednych ludzi i kobiet na rzecz władzy i dominacji innych. Podobnie jak większość sporów feministycznych i (de)konstrukcji kobiecości czy seksualności ma swoje źródło w Innym, dla którego nie istnieją wyrażenia słowne, a który pokazuje pewną lukę w przyjętych i dominujących społecznie heteroseksualnych normach i języku. Wspomniana Butler inspirowana postmodernizmem, demaskuje pozorną naturalność płci jako iluzję, tym samym podważa myśl feminizmu esencjalistycznego, który wszystkie teatralne gesty ciała traktuje jako podstawę kobiecości. Dla Butler płciowość jest przede wszystkim przygodna, umowna, a jej jedyna rola to podtrzymanie spójnej tożsamości jednostce, a ta dokonuje się poprzez język i słowa. Filozofię płci ukutą przez Butler trafnie konstatuje Justyna Wodzik ${ }^{13}$ :

11 Z. Bauman, Sztuka życia, s. 191.

${ }_{12}$ Za J. Mizielińską, Dekonstrukcje kobiecości. Podmiot feminizmu a problem wykluczenia, Gdańsk 2004, s. 207.

${ }^{13}$ Wodzik J., Czy kobieta istnieje? 
(...) płeć jest społeczną rolą, jaka zostaje nam przypisana i która łączy się z konkretnym zestawem norm, do których się ustosunkowujemy i wobec których jesteśmy oceniani. Płeć nie jest po prostu jedną z wielu ról społecznych, jakie mamy, ale jest ona nadrzędna wobec pozostałych, strukturyzuje życie. Tym samym płeć ma moc unifikacji życia, scalania różnych doświadczeń i porządkowania ich.

Bycie kobietą to splot wszystkich wydarzeń, impulsów oraz narzuconych przez społeczne kody misje, funkcje i zadania do wykonania. Owe zadania są umowne, kto bowiem w społeczeństwach patriarchalnych przez wieki decydował o tym, że kobiety mają gotować i wychowywać dzieci, a dla mężczyzn przeznaczono sferę zawodową, polityczną, edukacyjną? Współcześnie, kiedy nie istnieją już dawne zależności, normy, przypisywanie ról i protekcje rodów, czy rodzin pochodzenia, partnerzy decydując się na związek, sami podpisują umowę, kontrakt, coraz mniej dostosowując go do potrzeb innych, a jedynie własnych. Obecnie nie pożąda się uległych żon, umiejących rezygnować z siebie dla dzieci, męża i ogniska domowego, raczej uważa się taki typ kobiecości za nudny, pozbawiony wrażeń i silnie przypominający stereotyp „Matki Polki”. Solidna definicja owego stereotypu została dokonana przez Barbarę Smoczyńską, uzupełniona o komentarze Doroty ZaworskiejNikoniuk. Opisują one od lat pielęgnowany wzór kobiety matki, „której tożsamość oparta jest na macierzyńskim oddaniu i poświęceniu”, dotyczy to nawet sfery cielesnej i seksualnej.

Matka Polka nie próbuje dowartościować się poprzez cielesność i seksualność. Kobiecość zostaje tu wchłonięta (...) wyparta do podświadomości, unicestwiona, niedostępna, ukryta (co jest związane z chrześcijańskim mitem o ideale rodzicielki) ${ }^{14}$.

Matka Polka jako superbohaterka wypełnia swoją trudną rolę absolutnie sama, przemęcza się, nieustannie zamartwia o swoje dzieci i chce sprawować nad nimi kontrolę, między innymi poprzez kulinarny terror. Jak konstatuje Smoczyńska, "Jedzenie dla Matki Polki jest bowiem jedną z najistotniejszych czynności, sposobem na wyrażenie złości, miłości i innych uczuć". Współcześnie większość młodych kobiet, choć deklaratywnie odrzuca tego typu schemat funkcjonowania, wciąż jemu ulega, poprzez dźwiganie swoich ról matki, pracownicy i gospodyni domowej w samotności, bez większego udziału w rodzicielstwie mężów i ojców, poza finansowym.

Pionierska książka dla feminizmu, autorstwa Simone de Beauvoir Druga płeć, mówi o narzuconych społecznie rolach matki i żony, które absolutnie ubezwłasnowalniały kobiety, odbierając im prawo do wolności wyboru. Przeciwny pogląd głosiła z kolei esencjalistka Edith Stein, wzorując się na

${ }^{14}$ D. Zaworska-Nikoniuk, Ciąża i macierzyństwo na portalach internetowych. Aspekty edukacyjne, Olsztyn 2015, s. 33. 
doskonałej kobiecości reprezentowanej przez świętą Maryję - Matkę Jezusa. Stein drogę do kobiecości postrzegała przez najważniejszy cel, jakim jest macierzyństwo, jako wielki i piękny dar - rodzenia, karmienia i opiekowania się dziećmi, co według niej nie wyklucza kobiet z każdej innej dziedziny życia społecznego, w której podobnie jak mężczyzna jest sprawna i gotowa do powierzonych jej zadań.

Wspomniana, ważna dla ruchu feministycznego Simone de Beauvoir jawnie krytykowała bolesny proces wychowywania i uczenia dziewczynek, jak mają się stać kobietami wyłącznie przez pryzmat żony i matki, co argumentowała jako zaprzeczenie i rezygnację z podmiotowości, wolności i samospełnienia. Od ukazania tego bestsellerowego dla feminizmu tekstu w Polsce mija prawie pięćdziesiąt lat, kobiety coraz odważniej dekonstruują przyjęte kody opisywania ich ról tylko wokół rodziny, upubliczniają ciemne strony pełnienia roli matki ${ }^{15} \mathrm{i}$ żony. W kolorowej prasie mnożą się przykłady niezadowolenia czy frustracji związane $\mathrm{z}$ ich odgrywaniem ${ }^{16}$. Współczesne kobiety nie tylko mają prawo wyboru kiedy zostać matką czy żoną, co więcej - nikt od nich nie wymaga spełnienia się $w$ tych niegdyś społecznie narzuconych rolach. Zostały one zastąpione ustawiczną walką o samospełnienie, na polach: edukacji, kariery zawodowej, prestiżu, sławy, czy barwnej sfery kobiecych zainteresowań i pragnień, związanych głównie z posiadaniem (pięknego makijażu, ekstrawaganckiej garderoby, nietuzinkowego hobby związanego z walką na rzecz zwierząt, czy pięknego i koniecznie zdrowego ciała).

Kobiety nadal są rodzicielkami i to nie tylko swoich dzieci, jak w przypadku zjawiska "surogatek”. Coraz więcej matek i kontekstów o kobietach przeciążonych rolami ujawnia ciemne, a niejednokrotnie dramatyczne sceny podjętego trudu macierzyństwa. W cyberprzestrzeni krążą zdjęcia i opinie matek oszpeconych macierzyństwem ${ }^{17}$, podrapanych przez dzieci, zmęczonych do granic możliwości, których ciała zmieniają się po ciąży nie do poznania, które nie mają w ciągu dnia chwili wytchnienia, szarpane za bolące sutki przez bezlitosne potomstwo domagające się mamy nie tylko $\mathrm{w}$ dzień, ale i w nocy. Kobiety, których życie dotychczas pełne było przestrzeni, skoncentrowanych na samorozwoju i inwestycji w siebie, opisują macierzyństwo przede wszystkim jako ogromne poświęcenie i ogromny trud, którym nie potrafią i nie chcą sprostać. Co więcej, za ciężar współczesnego macierzyństwa winią społeczną presję i przymus, aby na bieżni zwanej życiowym spełnie-

15 Tamże, s. 34 .

16 Za przykład posłuży blog internetowy utworzony przez współczesne matki: http:/ / macierzyństwo- bez -lukru.blogspot/ [dostęp: 09.08.2018], lub fora, prasa feministyczna, reportaże, czasopisma krytyczne, np. „Bachor” - stanowią one opór przed ostracyzmem wobec mam uznanych za wyrodne.

17 D. Zaworska-Nikoniuk, Ciąża i macierzyństwo, 68-72. 
niem, czy wyzwoleniem, nie wypadały z życia zawodowego, z konkurencji i tempa, tym samym nie mogą pozwalać sobie na zwyczajne bycie singlem, dodając do swojej biografii bycie mamą, aby nie być społecznie posądzoną o egocentryzm. Ogrom ról i zadań, jakie współczesne kobiety z jednej strony wykonują, z drugiej nie są pewne, czy wynikają one $\mathrm{z}$ ich wewnętrznych zintegrowanych potrzeb, bo oprócz bycia troskliwą opiekunką społeczny świat wymaga od nich rozwoju zawodowego, prowokuje i rozprzestrzenia skłonność do nerwicy i depresji. Superbohaterki, które na zewnątrz godne podziwu radzą sobie całkiem dobrze, z trudem utrzymując pracę i nie zaniedbując obowiązków domowych, przeżywają lęk o przyszłość swoich dzieci i ogromne osamotnienie. Pełnią swoje role $z$ dala od stada, $z$ dala od wsparcia i pomocy rodziny pochodzenia, $\mathrm{z}$ dala od wyrozumiałości ze strony otoczenia, ale też codziennie narażone na złośliwe komentarze samych kobiet, które wybrały tylko poświęcenie dzieciom i mężczyzn nie nadążających za ich tempem rozwoju. Paradoks samospełnienia nie pozwala współczesnym matkom na zadowolenie i szczęście $\mathrm{w}$ obcowaniu z nowo narodzonym potomstwem, a tym bardziej na uzewnętrznienie tego, co potrzebne do bycia matką: cichości serca, stałości w partnerstwie, spokoju, dobroci dla innych i poświęcenia. Społeczny kulturowy narcyz nakazuje kobietom-matkom być przede wszystkim walecznymi, odważnymi, niezależnymi finansowo pięknymi i atrakcyjnymi, które nie mogą rezygnować z kariery zawodowej i z samej siebie na rzecz dzieci, bo to zagrozi ich samospełnieniu. Jeśli już mają dbać o dzieci, to tylko po to, aby zapewnić im dobrą - wszechstronną i prywatną edukację, bowiem dziś dominują, jak słusznie zauważa D. Zaworska-Nikoniuk: „Duże oczekiwania społeczne (...) związane z dążeniem do wychowania dzieci wysokiej jakości, mniejszą liczbą dzieci w rodzinie, wzrostem podmiotowości dziecka". Wszystkie te cele wychowawcze wydają się bardzo szlachetne, jednak są odpowiedzią rynku na wewnętrzne lęki i dysonans poznawczy, stawiający kobiety w roli opiekunek, żywicielek, wszechstronnych organizatorek życia rodzinnego i zawodowego oraz promujących mężczyzn także zlęknionych właśnie wszechmocą i siłą kobiet superbohaterek, które chcą prześcignąć mężczyzn na bieżni do satysfakcjonującego życia, spychając ich w zawodach o bycie lepszym, mającym więcej praw czy obowiązków?

Interesujące i niezwykle aktualne w kontekście opisywanych dylematów wyzwolenia dyskursy macierzyństwa przedstawiła Agnieszka Gromkowska-Melosik ${ }^{18}$. Autorka przedstawia cztery typy praktyk obecnych na poziomie świadomości wśród kobiet. Pierwsze dwa dotyczą kobiet wyzwolonych; w jednej grupie znajdują się te, które niezwykle cenią sobie dostęp do eduka-

18 A. Gromkowska-Melosik, Edukacja i (nie)równość społeczna kobiet. Studium dynamiki dostępu, Kraków 2001, s. 186-188. 
cji, pracy i kariery, przy jednoczesnym dzieleniu z partnerem obowiązków rodzicielskich, w drugiej zaś kobiety, które z równą determinacją i emancypacją oddają się obowiązkom zawodowym, nie mając wsparcia partnerskiego $\mathrm{w}$ wychowywaniu dzieci, tym samym pracują na dwa etaty, będąc obciążane rolami. Trzeci dostrzeżony przez badaczkę typ to macho matering, gdzie macierzyństwo to jedynie dodatek do osiągnięć i sukcesów zawodowych. Kobiety $\mathrm{z}$ tej grupy bardzo szybko po porodzie oddają swoje malutkie dzieci pod opiekę niań, żłobków, klubików, ewentualnie do rodziców. W tej grupie znajdą się także celebrytki, promujące wartość kobiety-matki, stanowiąc "dobrą reklamę" w kontekście niżu demograficznego i zagrożeń tożsamościowych wśród społeczeństw wysokorozwiniętych. W opisywanych dyskursach nie brakuje także kobiet, które świadomie rezygnują z prokreacji, traktując ten fakt wyłącznie jako wolny wybór, podkreślają sukcesy w innych formach aktywności, głównie skoncentrowanych wyłącznie na sobie.

Wszystkie powyższe przykłady współczesnych kobiet wpisują się we wszechobecną kulturę samodoskonalenia, nieustannego rozwoju i wpatrywania się w siebie. Macierzyństwo nie może spowalniać biegu, który jest kontynuowany szybko po porodzie, nie tylko w celu szybkiego powrotu do formy fizycznej. Nieustanna walka o utrzymanie sprawności w każdej dziedzinie życia to efekt samospełniających się oczekiwań społecznych, promujących kobiety tak silne, niezależne i wyzwolone, które poświęcenie dla innych (nawet dla własnych dzieci) traktują jako słabość. $Z$ kolei, przywiązanie do konsumpcyjnych pragnień, kosztownej garderoby, kawiarnianych spotkań z koleżankami, udanych egzotycznych wakacji - koniecznie tylko we dwoje, są przez same kobiety wyrazem uznania i powodem do dumy.

\section{Przywiązanie do przedmiotów. Niczym zwierzęta, których instynkty zanikły w niewoli...}

Do czasów Jeana Jacquesa Rousseau, a więc do XVIII wieku jedynym schematem socjalizacji dziewczynek było uczenie, jak mają się nieustannie podobać i stroić, aby być przedmiotem pożądania mężczyzn - ich ozdobą, zawsze cichą, pokorną i niewykształconą. Harriet Taylor ${ }^{19}$, wcześniej Mary Wollstonecraft w tekście z 1789 roku - Dochodzenie praw kobiet, uważa to za absolutne pogwałcenie praw kobiet, bo gdyby dać im możliwość edukacji i niezależności finansowej, nie zabiegałyby o bycie atrakcyjną, ale mądrą i odważną.

Współczesna kobieta socjalizowana do samodecydowania o sobie, swoim życiu, karierze zawodowej jest od najmłodszych lat poddawana dyscy-

${ }_{19}$ J. Mizielińska, Dekonstrukcje kobiecości, s. 69. 
plinie narzucanej przez popkulturę i uczona, że przedmioty ją otaczające zastąpią wspólnotę i ludzką obecność. Co więcej, przedmioty, które w ciągu życia zgromadzi, mają świadczyć o jej statusie społecznym, gwarantować niezależność i uznanie. Pazerny i wdzierający się w każdą sferę życia konsumpcjonizm towarzyszy małym dziewczynkom od przedszkola. Otoczone doskonałymi przedmiotami - bajecznymi lalkami przyozdobionymi w pstrokate stroje, wydające niezwykłe dźwięki, uzyskują nie tylko inspirację do zabaw bogatych w wyobraźnię, ale stanowią wzór do naśladowania. Warto zatem przyjrzeć się, jakie zabawki wybierają dziewczynki w wieku przedszkolnym. Dominują postaci bajkowe z filmów, które zaskakują, ale i mają na celu straszyć. Na przykład, lalki z firmy Matel - najpierw Barbie, obecnie Mounster High - lalki upiorki, przyjmujące intrygujące nazewnictwo, na przykład straszyciółka zamiast przyjaciółka, uczęszczające do straszyceum zamiast liceum, socjalizują dzieci do szokowania i wzbudzania strachu, jak same nazwy wskazują. A jedyną bronią w pokonaniu tego strachu ma być uroda, nietuzinkowe, pstrokate stroje i wzbudzanie podziwu ze strony mężczyzn, jak w przypadku bohaterki Apple White, będącej córką dobrej i pięknej Królewny Śnieżki.

Wczesne zabawy takimi lalkami kształtują postrzeganie stroju i rozumienie "piękna”, dlatego nie powinien dziwić fakt, że atrakcyjne i wymalowane Lolity ${ }^{20}$, których coraz więcej w szkolnych ławkach, to efekt wczesnej socjalizacji poprzez przedmioty i obecne kody w bajkach z serii na przykład Mounster High, zatytułowanej „Straszyceum”. Czujne kobiety dostrzegające siłę wewnętrzną, nie pozwolą sobą manipulować, nie będą podatne na presje i uczucia zazdrości, gniewu, dążąc do niepowodzenia innych kobiet, a jedynie wspierając wewnętrzną siłę, dzięki której czują prawdziwe uznanie i wartość Siebie, niezależnie od stanu posiadania.

Osoba prorozwojowa ma poczucie sprawstwa i jest przekonana, że sama wpływa na bieg zdarzeń, kreuje jakość swojego życia, dzięki wierze we własne możliwości. Jednocześnie ważne, aby zrozumieć, że wartość kobiet budowana jest od najmłodszych lat $\mathrm{w}$ relacji $\mathrm{z}$ ojcem. Psychoanalitycy coraz częściej spotykają anorektyczki, bulimiczki i zakupoholiczki z narcystyczną osobowością, głównie wśród dorosłych kobiet, które od najmłodszych lat albo nie miały kontaktu z ojcem, albo wyraźnie czuły z jego strony chłód emocjonalny i odtrącenie bliskości, słysząc negatywną krytykę w słowach „córko jestem Tobą rozczarowany". Problem ten trafnie zobrazowano w biograficznym filmie o niezwykle utalentowanej angielskiej piosenkarce Amy Winehouse. Bohaterka cierpiała w osamotnieniu, przeżywała każdą nieudaną relację,

${ }^{20}$ M. Ściupider-Młodkowska, Tożsamość wspótczesnych kobiet w kulturze narcyzmu, [w:] Kontrowersje wokót socjalizacji dziewcząt i kobiet, red. A. Matysiak-Błaszczyk, B. Jankowiak, Poznań 2016. 
szukając w mężczyznach uznania, którego nigdy nie doznała ze strony ojca. $\mathrm{W}$ relacji miłosnej zatracała się bez reszty, zapominając o swoich potrzebach, popadając w bulimię, anoreksję i uzależnienia, które doprowadziły ją w wieku dwudziestu ośmiu lat do tragicznej śmierci.

Co dziś kobiecie zapewnia uznanie i aprobatę, skoro nie są to wartości absolutne, doświadczane $\mathrm{w}$ rodzinie, nie jest to macierzyństwo, ani trwała relacja małżeńska czy rodzinna? Dzisiejsza kobieta sukcesu prezentuje markowe ubrania i dodatki jako narzędzie zewnętrznego pokazania prestiżu i zajmowania określonej pozycji społecznej. Wszechobecna socjalizacja poprzez przedmioty, zamiast wspólnoty, przywiązuje ludzi do wartości wokół posiadania.

„Metki, loga i marki to narzędzia służące ustalaniu prestiżu i pozycji społecznej. Marki i znaczki firmowe mają służyć «rozpoznaniu oraz «uznaniu tego, co w ostatnich latach określa się zwykle mianem tożsamości»" ${ }^{21}$. Ponadto, kobiety poszukują uznania w stanowiskach pracy, koniecznie $\mathrm{w}$ znanej korporacji, a co za tym idzie - w wysokim zarobkowaniu. Jednak najsilniej głód uznania dostrzegalny jest na wszelkich portalach społecznościowych, na których tak zwaną akceptację i uznanie można osiągnąć przez odpowiednie grupy i towarzystwo, które rzekomo zapewnią pozycję społeczną, do której większość kobiet aspiruje, czyniąc ze swojego życia niekończące się widowisko w postaci pięknych zdjęć, obrazujących zasoby, talenty, piękne zadbane ciała.

Relacje międzyludzkie odbijają relacje człowieka do wartości absolutnych. To, jak człowiek traktuje drugiego partnera oraz ludzi wokół siebie obrazuje ogólną odpowiedzialność za wspólnotowość, za umiejętność dzielenia się z Innymi. Zdaje się, że współcześnie brakuje miejsca dla innych, nie ma też zwyczajnie czasu na rozwój miłosnych relacji, w zamian zostaje bieżnia - jako symbol bezrefleksyjnego ruchu w celu lepszej kondycji fizycznej i psychicznej. Bieżnia symbolizująca ruch nigdy nie będzie drogą do osiągnięcia satysfakcjonującego celu, bo jedynym jej celem jest bezustanny bieg.

Reasumując, kobieta biegnąca na bieżni, to nie tylko kobieta poddająca swoje ciało ciągłej dyscyplinie, lecz również ta, która uwierzyła, że ciągły bieg zagwarantuje jej uznanie, a ciągła zmiana tożsamości ulepszy jej kondycję psychiczną i zagwarantuje sukces. Kobieta współczesna biegnie, a to powoduje niestałość i ambiwalencję jej pragnień. Można się zatem zastanowić, czy taki bieg nie symbolizuje ucieczki - ucieczki od stałości swojej tożsamości. Zdaje się, że dla takiej kobiety bycie w ruchu jest przyjemnością i gwarantem sukcesu, zatrzymanie się, urefleksyjnienie - to porażka.

${ }^{21}$ Z. Bauman, Sztuka życia, s. 27. 


\section{Zakończenie}

Kobiety owładnięte, czy też przytłoczone, narcyzmem kulturowym nie są szczęśliwe, brakuje im instynktu, czują się osamotnione, a jedyne zapełnienie pustki emocjonalnej wypełnia im trening nad udoskonaleniem siebie. Brylując swoim zewnętrznym pięknem, jednocześnie pogardzają wszystkimi, którzy ulegają tej manipulacji, cierpią na niezaspokojony głód doświadczeń emocjonalnych. Nie uwewnętrzniają zakorzenione w nich od zawsze pragnienie miłości bezinteresownej, bo miłość traktują jako poświęcenie (w przypadku macierzyństwa) czy uległość i poniżenie (w przypadku małżeństwa).

Społeczeństwo zorganizowane wokół konsumpcji i przyjemności narzuca jednostkom wszelkie formy zachowania narcystycznego, jak na przykład celebrowanie swoich osiągnięć i barwnego życia za pomocą zdjęć typu selfie, które mają na celu uwiecznić chwilę, ale też rozbudzić ciekawość innych, aby wylansować krótkie i ulotne historie z jakże barwnego i zawsze "uśmiechniętego" życia.

Obok tego co uzewnętrzniane mamy do czynienia z powtarzającym się rozczarowaniem w związkach, prowokacją i wzajemną walką o emocjonalność. Dlatego większość mężczyzn uważa, że bycie wrażliwym, czułym i współczującym zagraża ich poczuciu bezpieczeństwa, czy staje się przeszkodą w osiągnięciu satysfakcji seksualnej. Z kolei, kobiety oczekują od nich bycia dobrymi przyjaciółmi i kochankami jednocześnie, twierdząc, że są przez mężczyzn zdominowane, osłabione, nie widząc, że to warunki społeczno-kulturowe narzucają uległość, manipulacje, czy dominacje ról.

Rozważania nad współczesną kondycją kobiet z jednej strony nie są wolne od dekonstrukcji kobiecości, takiej która biegnie ku wyzwoleniu, ale podlega też alienacji społecznej przez inne kobiety, uznające tradycyjny podział ról, przy zachowaniu swojej superbohaterskiej kondycji społecznej. $\mathrm{W}$ moim odczuciu, nadmiar otaczających spraw przypisanych współczesnym kobietom odbiera im wolny wybór, a kulturowy narcyz, wciąż głodny miłości i uznania, igra i powątpiewa z ich wewnętrznej, biologicznej, czy też od lat pielęgnowanej przez mądre babcie i matki siły kobiecego piękna i życia. Edukacja i socjalizacja, mająca na celu wzmacniać wartość kobiet bez odbierania im ich wewnętrznej siły i kobiecości, ma kluczowe znaczenie dla współczesnej pedagogiki społecznej.

\section{BIBLIOGRAFIA}

Bauman Z., Sztuka życia, Warszawa 2009.

Bauman Z., Retrotopia. Jak rządzi nami przeszłość, Warszawa 2018.

Estes C.P., Biegnąca z wilkami. Archetyp dzikiej kobiety w mitach i legendach, Poznań 2001. 
Gromkowska-Melosik A., Edukacja i (nie)równość społeczna kobiet. Studium dynamiki dostępu, Kraków 2001.

Lacan J., Pisma techniczne Freuda, Warszawa 2017.

Lasch Ch., Kultura narcyzmu, Warszawa 2015.

Mizielińska J., Dekonstrukcje kobiecości. Podmiot feminizmu a problem wykluczenia, Gdańsk 2004.

Nast M., Pokolenie Ja. Niezdolni do relacji, Warszawa 2017.

Ściupider-Młodkowska M., Tożsamość wspótczesnych kobiet w kulturze narcyzmu, [w:] Kontrowersje wokót socjalizacji dziewcząt i kobiet, red. A. Matysiak-Błaszczyk, B. Jankowiak, Poznań 2016.

Ściupider-Młodkowska M., Miłość w epoce Ja. Studium socjopedagogiczne, Poznań 2018.

Wodzik J., Czy kobieta istnieje? Spór o pojęcie kobiecości pomiędzy esencjalizmem i antyesencjalizmem we wspótczesnej myśli feministycznej, Warszawa 2016.

Zaworska-Nikoniuk D., Ciąża i macierzyństwo na portalach internetowych. Aspekty edukacyjne, Olsztyn 2015. 